\title{
Factors Influencing Female Enrolment in Science Education Programmes in Distance Learning Institutions in South-West, Nigeria
}

Oladele Esther Oluwasayo and Adeniyi Comfort Olawumi

Science Education Department, Distance Learning Institute, University of Lagos, Nigeria

ISSN: 2788-6298

DOI : https://doi.org/10.35293/tetfle.v2i1.90

\begin{abstract}
This study investigated the factors influencing enrolment of female learners in Science Education programmes of three Distance Learning Institutes in South-West, Nigeria. The objectives of the study were to explore socioeconomic, personal and cultural factors that influence the enrolment of women into Distance Learning Institute. The target population was all female learners in the Departments of Science Education. This study was guided by the facilitation theory using a questionnaire as the research instrument. The researchers sampled 280 female learners in Science Education programmes of these Distance Learning Institutes. Three research questions were raised and analysed. The data obtained were analysed using mean, standard deviation and also presented in percentages. Findings revealed that socioeconomic factors such as finance as well as personal factors, including attaining social and academic satisfaction could influence the enrolment of women in Science Education programmes. The study revealed that majority of the women are employed, though faced with several challenges that hinder their studies. The study recommended ways of overcoming these challenges and urged the government and stakeholders to implement these recommendations for the development of Distance Education.
\end{abstract}

Keywords: Cultural factor, Personal factor, Socioeconomic factor, Distance Education, Female student enrolment. 
Volume 2, 2020

\section{Introduction}

Distance Education is seen as an alternative to regular university education. According to Osipita (2016), Distance education has been seen as a major advancement in Nigeria, as it refers to the mode of teaching and learning which deals with learner and teacher being separated from each other in time and space, with focus on distance teaching and learning. According to Gensler (2014), the main feature of distance education is the physical distance between the learner and the teacher. The learners, therefore, are responsible for their own learning. Apart from the use of printed instructional materials developed for distance learning, distance learning also focuses on learners and their response to instructions by their e-tutors and facilitators (Leslie \& Elizabeth, 2010). All over the world, Distance Education is seen as a means for a large number of learners to access quality education wherever they are at any time and space (Gensler, 2014). Through Distance Education, many people with family and work commitment can have access to quality education (Stephanie, 2013). Despite the various benefits of Distance Education, it is faced with some challenges, among which include lack of information for course of study, delayed feedback on assignment and release of results and poor lecturers' remuneration (Chawinga \& Zozie, 2016). Markova, Glazkova and Zaborova (2017), also found that distance learners face many challenges, especially with regards to effective communication patterns and teaching practices. Again, Musingafi et al., (2015) have shown that distance learners face challenges such as insufficient time of study, ineffective feedback, difficulty in access and use of ICT and lack of study materials.

Females (women) are held responsible for raising children and taking care of their homes and families. When girls and women receive support along with mentorships, learning through smart technology from boys and men, respectively, their leadership skills and capabilities are built (O'Neil, Plank \& Domingo, 2015). On the other hand, Sahni (2015) emphasised that it is inherently valuable and a girl's right to be educated. Education helps females claim their rights and realise their potential in the economic, political and social areas (Sahni, 2015). It is also the single most powerful way to lift people out of poverty.

Agwi, Amadike \& Ejimaji (2016) asserted that another notable strategy for improving female interest to enrol for science- and technology-related courses, is for teachers to ensure that their female learners are encouraged, especially those that excel in science-related subjects.

Unfortunately, in Nigeria today, much has not been achieved in terms of women education. Women and girls have continued to suffer various forms of discrimination, deprivation and marginalisation in terms of receiving and attaining formal education at all levels. All of these compared with the male counterparts; due to unequal access to education opportunity resulting in high level of illiteracy among the female, especially in science- and technology-related areas.

CONTACT: Oladele Esther Oluwasayo eoladele@unilag.edu.ng

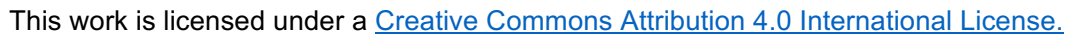


Education for all understood in terms of equal access to education is not enough. Equality and future development of societies are, therefore, dependent on providing high-quality science education for all (Ekine \& Abay, 2013). It should be an intrinsic part of any strategy to address the gender-based discrimination against females that remains prevalent in many societies.

The various Distance Learning Institutes considered have about $60 \%$ of the distant learners as females who are employed or in business. They are enrolled in various Science Education courses offered in the Distance Learning Institutes. In order to contribute to the scarce empirical research in this area in Nigeria, and with a focus on the barriers to education and economic participation that girls and women face such as early marriage, distance to school, cultural values, security concerns and cost of schooling among others; this research, therefore, explores the various factors influencing enrolment of females in Science Education programs of the University of Lagos (DLI), University of Ibadan (DLC) and National Open University of Nigeria (NOUN). To this end, the study will specifically:

1. Investigate the socioeconomic factors that influence enrolment of females into Science Education programmes of the Distance Learning Institutes.

2. Identify cultural factors that influence female enrolment into Science Education programmes of the Distance Learning Institutes.

3. Determine the personal factors that influence enrolment of females into Science Education programmes of the Distance Learning Institutes.

\section{Problem Statement}

Female learners' enrolment into Distance Learning Institute has consistently been comparatively low, and there is the need to investigate how female learners make their science subject enrolment decisions. Among all the main departments in Distance Learning Institute, the Science Education Department receives one of the least, if not the least female student admissions every year. This consequently affects the number of female learners opting for science-oriented courses. A review of a number of research studies on learners' subject choice and learners' attitudes towards sciences was completed. Some of these research works were about young learners whose courses and subject choices could be heavily influenced by their parents because they were still under the care and control of their parents. However, most of the respondents (learners) in the present study are relatively mature and, in most cases, independent individuals who may not be necessarily influenced in their choices of subject by their parents and family. Therefore, there is the need to establish the factors affecting the interest of female learners in science-oriented courses in the current context, hence the need for this study. It is against this background that the researcher sought to establish the factors that influence the enrolment of female learners into science Education courses of the Distance Learning Institutes. The study will then provide answers to the following questions:

CONTACT: Oladele Esther Oluwasayo eoladele@unilag.edu.ng

This work is licensed under a $\underline{\text { Creative Commons Attribution } 4.0 \text { International License. }}$ 
1. What socioeconomic factors influence the enrolment of females into Science Education programmes?

2. What cultural factors influence enrolment of females into Science Education programmes?

3. What personal factors influence enrolment of females into Science Education?

\section{Theoretical Framework}

This study was guided by the Facilitation theory. The Facilitation theory developed by Davis and Francis (2019) was adopted because of its emphasis on "natural eagerness to learn" and 'person-centred learning'. It actually started with the assertion that someone cannot teach the other person directly. Hence, the focus is on the role of positive learner-teacher relationship in enabling learning.

One of the basic premises of this theory is that learning is possible because human beings have a "natural eagerness to learn" and they (human beings) are responsible for, and at the centre of the learning process (person-centred learning). E-learning is possible only because individuals who opt for it are self-driven and eager to learn despite their location in relation to learning institutions. The role of the teacher is to act as a facilitator, no amount of effort on the part of the teacher can guarantee success unless the learner has a desire and predisposition to learn.

The facilitation theory over the years is of the notion that learning involves changing one's selfconcept. Such changes may involve discovering one's strengths or weaknesses. However, Davis and Francis (2019), opine that the facilitation theory also implies that, learners must blend themselves to the mode of education in which they choose for knowledge acquisition. A freshly perceived self-concept has a consolidating impact on learning in that it allows the learner to attack a target skill with confidence.

Hidden in the non-direct facilitative approach is the assumption that learners can find the information by themselves (teachers merely facilitate that process), an assumption which downplays the role of information transmission and underestimates the contribution of teaching. Teacher-student contact is the moderating variable that provides the interaction effect. Teachers who are able to establish and maintain positive and personal relationships with learners tend to experience better achievement and results, higher-order thinking and improvements in self-regard.

\section{Methodology}

This study adopted a descriptive survey design. The target population for the study comprises all females in Science Education Departments; Distance Learning Institute (DLI), University of

CONTACT: Oladele Esther Oluwasayo eoladele@unilag.edu.ng

This work is licensed under a $\underline{\text { Creative Commons Attribution } 4.0 \text { International License. }}$ 
Volume 2, 2020

Lagos, Distance Learning Centre (DLC), Ibadan and National Open University of Nigeria (NOUN). An 18-item, self-structured modified four-point Likert scale questionnaire titled 'Factors Influencing Female Enrolment in Science Programmes' (FIFEISP) was used to elicit information from the sample. Three hundred (300) copies of questionnaire were distributed and two hundred and eighty (280) were retrieved. This instrument was validated by two tests and measurement experts from the Faculty of Education, University of Lagos. A pilot test was conducted using 25 female distance learners from a university outside the sampled institutions to ascertain the reliability of the instrument and a Cronbach Alpha value of 0.78 was obtained. The data obtained were analysed using mean, standard deviation and also presented in percentages. Mean score was used to answer the research questions stated, the criterion mean was taken as 2.50 (the average $1+2+3+4$ divided by 4 is 2.5 ; where 4 stand for Strongly Agree, 3 for Agree, 2 for Disagree and 1 for Strongly disagree) being the reference point), therefore any mean score below 2.50 was taken as disagree, while mean score of 2.50 and above was taken as agree. The cut-off point for accepting or rejecting an item was fixed at 2.50 (Criterion). Also, the combined percentages of agree/strongly agree were combined and seen as agreed and the percentages of disagree/strongly disagree were seen as disagree.

\section{Results and Discussion}

Analysis of Respondents based on the Research Questions:

Research Question 1: What socioeconomic factors influence the enrolment of female learners into Science Education programmes? 
Teacher Education Through Flexible Learning in Africa

Volume 2, 2020

Table 1

Influence of Socioeconomic Factors on the Enrolment of Female Learners into Science

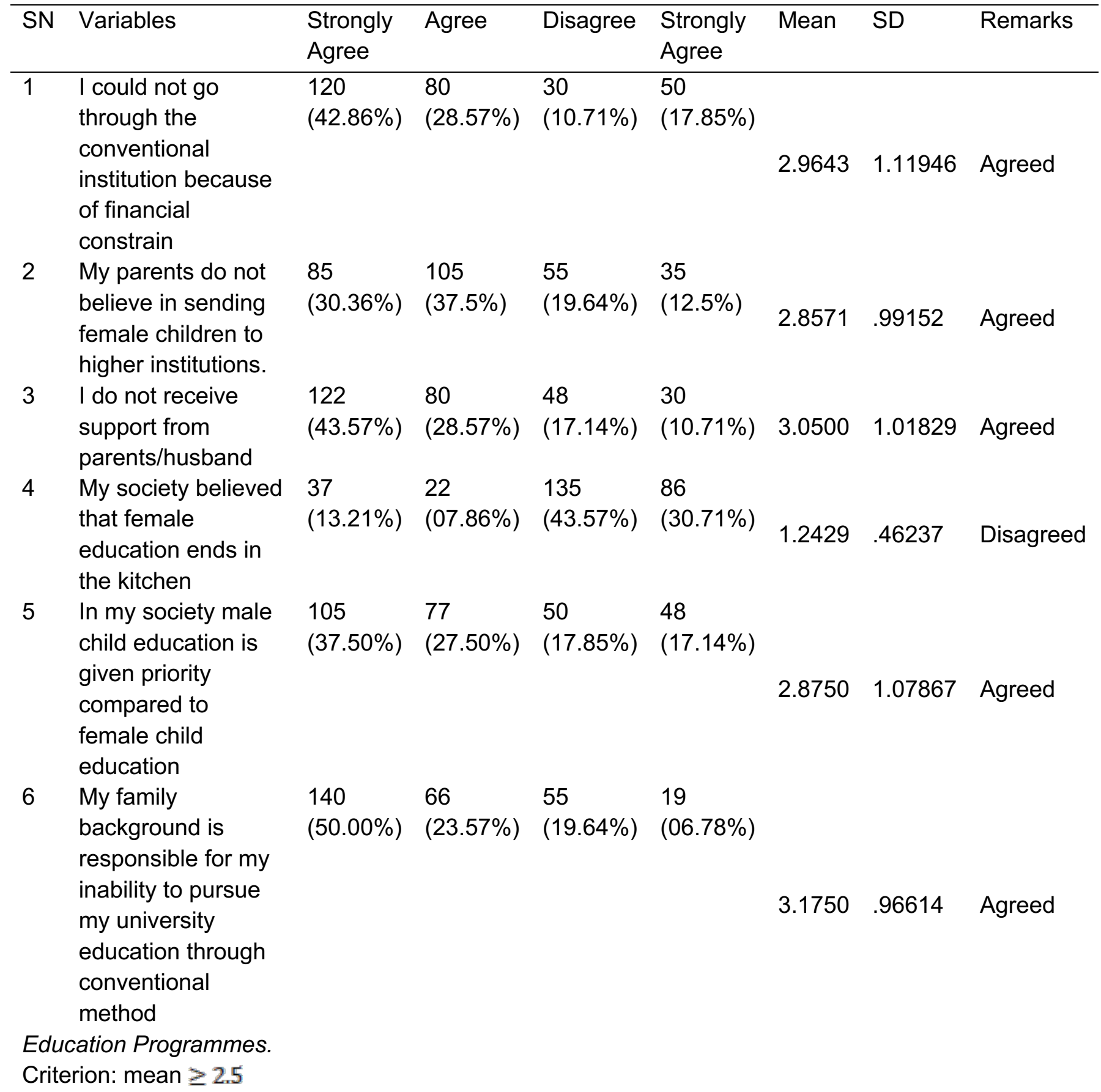

CONTACT: Oladele Esther Oluwasayo eoladele@unilag.edu.ng

(c) (1) This work is licensed under a Creative Commons Attribution 4.0 International License. 
Volume 2, 2020

Table 1 shows only one statement was disagreed with mean value less than 2.5 , which means that the society no longer believes that female education ends in the kitchen. The remaining statements were agreed because their mean values were above 2.50. Also, the sums of percentages for strongly agree and agree were greater than $50 \%$ for all variables identified in table 1 except for item 4 which indicate that Socioeconomic factors, influence enrolment of female learners into Science Education programmes.

Research Question 2: What cultural factors influence enrolment of females into Science Education programmes?

Table 2

Influence of Cultural Factors on the Enrolment of Females into Science Education Programmes

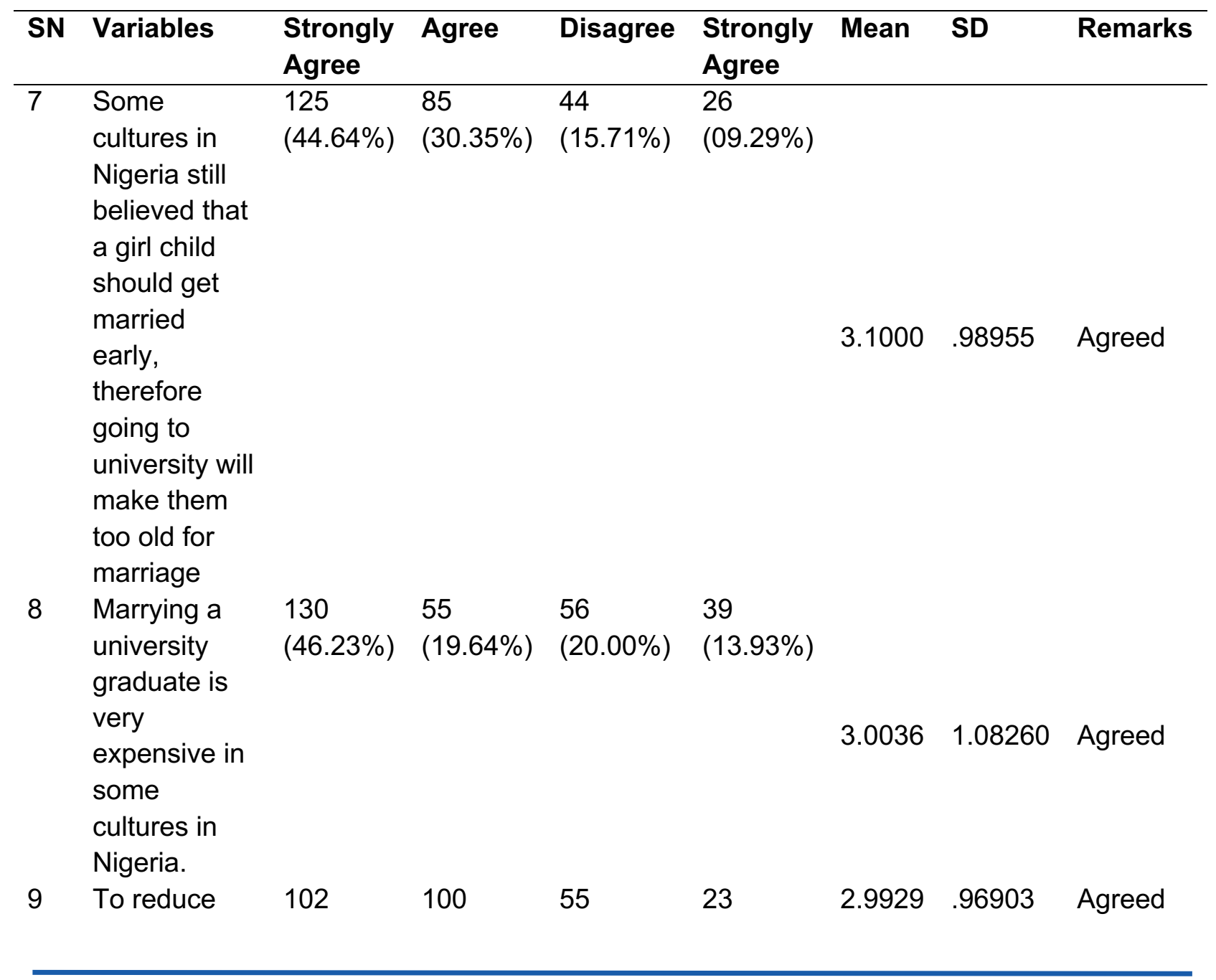

CONTACT: Oladele Esther Oluwasayo eoladele@unilag.edu.ng 
Volume 2, 2020

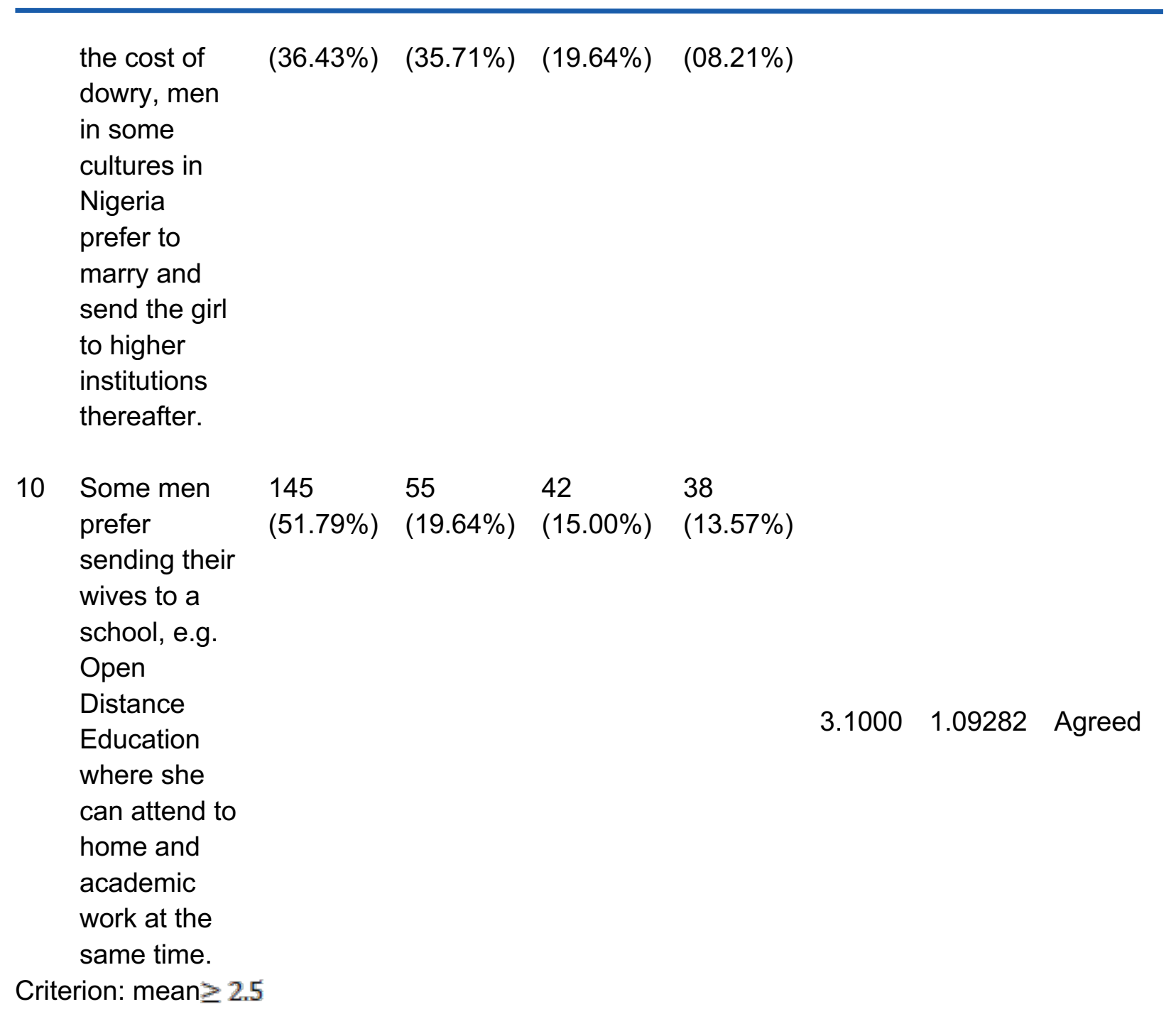


Volume 2, 2020

Table 2 shows all statements were agreed because their mean values were above 2.50 and the sum of percentages for strongly agree and agree were greater than $50 \%$ which implies that the cultural factors identified above, influence the enrolment of female learners into Science Education programmes and Distance Learning Institutes.

Research Question 3: What personal factors influence enrolment of females into Science Education?

Table 3

Influence of Personal Factors on Enrolment of Female Learners into Science Education Programmes.

\begin{tabular}{|c|c|c|c|c|c|c|c|c|}
\hline SN & Variables & $\begin{array}{l}\text { Strongly } \\
\text { Agree }\end{array}$ & Agree & Disagree & $\begin{array}{l}\text { Strongly } \\
\text { Agree }\end{array}$ & Mean & SD & Remarks \\
\hline 11 & $\begin{array}{l}\text { I could not go } \\
\text { through the } \\
\text { conventional } \\
\text { institution } \\
\text { because I } \\
\text { could not pass } \\
\text { JAMB/other } \\
\text { entrance } \\
\text { examination }\end{array}$ & $\begin{array}{l}110 \\
(39.29 \%)\end{array}$ & $\begin{array}{l}55 \\
(19.64 \%)\end{array}$ & $\begin{array}{l}80 \\
(28.57 \%)\end{array}$ & $\begin{array}{l}35 \\
(12.50 \%)\end{array}$ & 2.9643 & 1.11946 & Agreed \\
\hline 12 & $\begin{array}{l}\text { Getting } \\
\text { admission into } \\
\text { Nigerian } \\
\text { conventional } \\
\text { university } \\
\text { involves a lot } \\
\text { of processes } \\
\text { and stress }\end{array}$ & $\begin{array}{l}110 \\
(25.14 \%)\end{array}$ & $\begin{array}{l}80 \\
(28.57 \%)\end{array}$ & $\begin{array}{l}50 \\
(17.85 \%)\end{array}$ & $\begin{array}{l}40 \\
(14.28 \%)\end{array}$ & 2.8571 & .99152 & Agreed \\
\hline 13 & $\begin{array}{l}\text { I have tried } \\
\text { getting } \\
\text { admission into } \\
\text { some } \\
\text { conventional } \\
\text { university } \\
\text { before now }\end{array}$ & $\begin{array}{l}122 \\
(43.57 \%)\end{array}$ & $\begin{array}{l}80 \\
(28.56 \%)\end{array}$ & $\begin{array}{l}40 \\
(14.28 \%)\end{array}$ & $\begin{array}{l}38 \\
(13.57 \%)\end{array}$ & 3.0500 & 1.01829 & Agreed \\
\hline
\end{tabular}

CONTACT: Oladele Esther Oluwasayo eoladele@unilag.edu.ng

(c) (1) This work is licensed under a Creative Commons Attribution 4.0 International License. 
Volume 2, 2020

\begin{tabular}{|c|c|c|c|c|c|c|c|c|}
\hline 14 & $\begin{array}{l}\text { I need to work } \\
\text { to sustain } \\
\text { myself in } \\
\text { school }\end{array}$ & $\begin{array}{l}130 \\
(46.43 \%)\end{array}$ & $\begin{array}{l}70 \\
(25.00 \%)\end{array}$ & $\begin{array}{l}30 \\
(10.71 \%)\end{array}$ & $\begin{array}{l}50 \\
(17.85 \%)\end{array}$ & 3.2429 & .86237 & Agreed \\
\hline 15 & $\begin{array}{l}\text { ODE system of } \\
\text { education is } \\
\text { more flexible, } \\
\text { one can } \\
\text { combine work, } \\
\text { marriage and } \\
\text { academic work }\end{array}$ & $\begin{array}{l}145 \\
(51.78 \%)\end{array}$ & $\begin{array}{l}70 \\
(25.00 \%)\end{array}$ & $\begin{array}{l}50 \\
(17.85 \%)\end{array}$ & $\begin{array}{l}15 \\
(05.36 \%)\end{array}$ & 2.8750 & 1.07867 & Agreed \\
\hline 16 & $\begin{array}{l}\text { I opted for } \\
\text { ODE } \\
\text { programmes } \\
\text { since I could } \\
\text { not secure } \\
\text { admission into } \\
\text { conventional } \\
\text { university }\end{array}$ & $\begin{array}{l}120 \\
(42.86 \%)\end{array}$ & $\begin{array}{l}85 \\
(30.36 \%)\end{array}$ & $\begin{array}{l}45 \\
(16.07 \%)\end{array}$ & $\begin{array}{l}30 \\
(10.71 \%)\end{array}$ & 3.1750 & .96614 & Agreed \\
\hline 17 & $\begin{array}{l}\text { My job will not } \\
\text { allow me to } \\
\text { study through } \\
\text { conventional } \\
\text { university } \\
\text { system }\end{array}$ & $\begin{array}{l}89 \\
(31.79 \%)\end{array}$ & $\begin{array}{l}80 \\
(28.57 \%)\end{array}$ & $\begin{array}{l}60 \\
(21.43 \%)\end{array}$ & $\begin{array}{l}51 \\
(18.21 \%)\end{array}$ & 2.9964 & 1.14064 & Agreed \\
\hline 18 & $\begin{array}{l}\text { To achieve my } \\
\text { goal and desire } \\
\text { in life, I need to } \\
\text { find an } \\
\text { alternative to } \\
\text { get education } \\
\text { which I could } \\
\text { not get through } \\
\text { conventional } \\
\text { institutions }\end{array}$ & $\begin{array}{l}102 \\
(36.43 \%)\end{array}$ & $\begin{array}{l}90 \\
(32.14 \%)\end{array}$ & $\begin{array}{l}58 \\
(20.71 \%)\end{array}$ & $\begin{array}{l}30 \\
(10.71 \%)\end{array}$ & 3.2393 & .91379 & Agreed \\
\hline
\end{tabular}

CONTACT: Oladele Esther Oluwasayo eoladele@unilag.edu.ng

(c) $\$$ (2) This work is licensed under a Creative Commons Attribution 4.0 International License. 
Volume 2, 2020

Table 3 shows all statements were agreed because their mean values were above 2.50 and the sum of percentages for strongly agree and agree were greater than $50 \%$ which implies that all the itemised personal factors above, influence enrolment of female learners into Science Education programmes.

\section{Discussion}

Responses on the Influence of Socioeconomic factors affecting the enrolment of female Learners into science education programmes, reveals that personal, cultural and socioeconomic factor such as finance can influence the enrolment of female in science programmes. In this study, learners also agreed that their parents do not believe in sending female children to higher institutions. These findings, therefore, corroborate the work done by Nfor (2020) on the socioeconomic status and female enrolment in Engineering and Technology Programmes in Anglo- Saxon State Universities of Cameroun, where the socioeconomic status of parents was observed to correlate significantly to female learners' enrolment in engineering and technology. It was therefore recommended that parents should feature in their wards' academic activities. However, Ndirika and Agommuoh (2017) and Ekine and Abay, (2013), have recommended that it is paramount to ensure access to and improve quality of education for girls and women as well as to remove every obstacle that hampers their active participation. This is in line with the report by the United Nations children's fund New York (2018), that "Girl education is a key priority for sustainable development, fundamental to ensuring their rights and essential to delivery on the promise to leave no one behind". However, in order to improve Girl Education, as well as education for all, Bashir and Usma (2018) in their work have submitted that there is an urgent need for improving the overall skills of personnel involved in Distance Learning, so that they can become productive in educating distance learners and hereafter enhance the economy.

Also, it was observed that all respondents in this study agreed that cultural factors influence female learners' enrolment into distance education programmes. This is reflected in the 'agreed' response from respondents about statements such as 'the belief that a girl child should get married early', 'going to university will make them too old for marriage',' marrying a university graduate is very expensive in some culture in Nigeria', 'to reduce the cost of dowry, men in some culture in Nigeria prefer to marry and send the girl to higher institutions thereafter'. Also, some men prefer sending their wives to Open and Distance Learning institutions where they can attend to home and academic work at the same time. In view of these, Pozdnyakova and Pozdnyakov (2017) discovered that conditions at home can have a very great impact on the academic performance of distance learners as much learning is required at home in distance learning programmes. Also, findings from this study are supported by the observations made by Idris (2012) that socio-cultural religious affinities and practices/values, as well as parental

CONTACT: Oladele Esther Oluwasayo eoladele@unilag.edu.ng

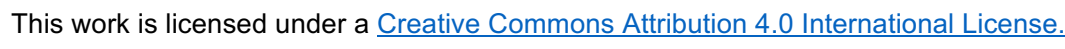


Volume 2, 2020

influence, have a significant effect on female enrolment into technology-based programmes in federal polytechnics in Northern states of Nigeria.

Findings from this study, also show that personal factors including attaining social and academic satisfaction can influence the enrolment of women in Science programme which is in line with the literature that reports that most women in leadership have started participating early in leadership activities and education since adolescents (O'Neil, Plank and Domingo, 2015). These, therefore, improve self-efficacy and self-confidence. Although, Zaborova and Markova (2016), have reported that students in online environments tend to be isolated and confused, thereby having reduced learning effectiveness and satisfaction. Therefore, it can be said that a woman (female) with a high level of self-efficacy and self-confidence will show an optimal positive attitude when facing the challenges of studying among other responsibilities at home and work. Stephanie (2013) however, observed that women are hit hard with family responsibilities just when they need to meet research goals.

The facilitation theory developed by Davis and Francis (2019) was adopted in this study, because it accentuates "natural eagerness to learn" and 'person-centred learning'. Hence, learners are said to be responsible for their own learning. This study has, therefore, revealed various factors influencing female enrolment into science education programmes in Distance Learning Institutes, South-West, Nigeria. Most importantly, the personal factors which are substantiated by the facilitation theory that emphasises that every learner, is eager to learn and should show the ability for personalised learning, as this was specifically revealed (Table 3 , questions 15 and 18) by how the learners are eager and enthusiastic to learn by self-motivation and person-centred form of learning. They encouraged themselves by not giving up acquiring tertiary education, in the face of various challenges, which includes the inability to secure admission into conventional universities and having to combine work, marriage and academic work.

\section{Conclusion and Recommendations}

From the study, it can be deduced that all factors studied; socioeconomic, cultural and personal factors have a great influence on enrolment of females into Science Education programmes of the Distance Learning Institutes in South-West, Nigeria.

Most females enrolled in distance education programs are working-class adults who are influenced by socioeconomic, cultural and personal factors. The driving force behind enrolment of these females in Distance Learning Institutes is the desire to gain more knowledge to enhance professionalism in their field of practice as well as finance; hence the need for a good job to sustain them while going to school. Substantiating the essence of adopting the facilitation

CONTACT: Oladele Esther Oluwasayo eoladele@unilag.edu.ng

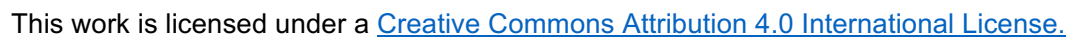


Volume 2, 2020

theory, is the fact that, findings from the study has shown that women from the sampled institutes are ready to study through Distance Learning Institute programs, to catch up with their male counterparts. Even though they are faced with financial constraints, they are determined to complete the program. Hence, eliminate gender inequalities and promote equity.

Based on these findings, the following recommendations are made:

- Further research into other related factors posing as barriers to female learners' enrolment into Science education programmes should be done.

- Distance learning institutions should reduce the price of their school fees as finance is a major socioeconomic factor found in this study as a challenge to female student enrolment.

- The government should implement a lending financial policy which is learner-friendly to distance learners who are self-sponsored. For instance, women should be offered more time to pay-back their loans from academic financial institutions. As a result, every obstacle to the enrolment of female learners into Science programmes should be looked into and removed, so that more women would be encouraged to acquire education through the distance learning mode.

\section{Disclosure Statement}

No potential conflict of interest was reported by the authors.

\section{References}

Agwi, V. I. A., Amadike, O. \& Ejimaji, E. E. 2016. Critical Appraisal and Evaluation of Teaching and Learning Effects in Technical Colleges in Rivers State. Am demit StholarJhip Journal 11 (1), 179-198.

Bashir, M. \& Usma, I.A. 2018. Role of Open and Distance Learning (ODL) In Technical Vocational Education and Training in Nigeria. ATBU Journal of Science, Technology and Education. 6 (3).

Chawinga, W.D \& Zozie, P.A. 2016. Increasing access to higher education through Open and Distance Learning: empirical findings from Mzuzu University, Malawi. International Review of Research in Open and Distributed Learning, 17:1-20.

Davis, B. \& Francis, K. 2019. 'Facilitation Theory' in Discourses on Learning in Education. Available at http://www.learningdiscourses.com. Accessed on 15 October 2019.

CONTACT: Oladele Esther Oluwasayo eoladele@unilag.edu.ng

This work is licensed under a Creative Commons Attribution 4.0 International License. 
Volume 2, 2020

Ekine, A.O., \& Abay, N.A. 2013. Enhancing Girls' participation in Science in Nigeria. A Driver for National development and social equality. Accessed January 14, 2017. Available at http://www.cssia.org/pdf/20000193. Accessed on 15 October 2019.

Gensler, L. 2014. From Correspondence Courses To MOOCs: The Highlights Of Distance Learning Over The Ages. Forbes. Forbes Magazine.

Idris, A. 2012. Effects of multi-dimensional variables on female enrolment in technology programmes in federal polytechnics in the Northern Geo-Political Zones of Nigeria: Implication for Curriculum Review (Ph.D. Thesis) submitted to Ahmadu Bello University, Zaria. Available at www.kubanni.abu.edu.ng. Accessed on 20 October 2019.

Leslie, S., \& Elizabeth, E. 2010. Perceptions of disability and access to inclusive education in West Africa; a comparative case study in Dakar. Senegal Inclusive Communities: Inclusive Education. Available at http://www.internationaljournalofspecialeducation.com. Accessed on 28 October 2019.

Markova, T., Glazkova, I., \& Zaborova, E. 2017. Education, Health and ICT for a Transcultural World. 7th International Conference on Intercultural Education EDUHEM 2016, 15-17 June 2016. Almeria, Spain Quality Issues of Online Distance Learning. Procedia - Social and Behavioral Sciences 237: $685-691$.

Musingafi, M. C. C., Mapuranga, B., Chiwanza, K., Zebron, S. 2015. Challenges for Open and Distance Learning (ODL) Students: Experiences from Students of the Zimbabwe Open University Journal of Education and Practice, 6 (18) pp 59-66. Available at http://iiste.org/Journals. Accessed on 14 October 2019.

Ndirika, M. C., \& Agommuoh, P. C. 2017. Investigating factors influencing Girls Participation in Science and Technology Education in Nigeria. Journal of Research and Methods in Education, 7(30): 2320-7388pp.

Nfor J. C. 2020. Socioeconomic status and female enrollment in engineering and technology programmes in Anglo-Saxon state universities of Cameroon. International Journal of Trend in

CONTACT: Oladele Esther Oluwasayo eoladele@unilag.edu.ng 
Volume 2, 2020

Scientific Research and Development (ijtsrd), ISSN: 2456-6470, Volume-4 | Issue-3, pp.10151020. Available at https://www.ijtsrd.com/papers/jitsrd30789. pdf. Accessed on 28 October 2019.

O'Neil, T., Plank, G, and Domingo, P. 2015. Support to women and girls' leadership: A rapid review of the evidence. London: Overseas Development Institute.

Osipita, O. 2016. Towards improving distance education in Nigeria with virtual technology. Interlink Continental Journal of Educational Research and General Studies, 2(1), 1-6.

Pozdnyakova, O., \& Pozdnyakov,A. 2017. Adult students' problems in the Distance Learning. Procedia Eng.178, 243-248. http:// doi.org/10.1016/j.proeng.2017.01.105.)

Pozdnyakova, O., \& Pozdnyakov,A. 2020. Distance Learning as an option to overcome the learning barriers of Adult Female students. In: Kabashkin i., Yatskiv I., Prentkovskis O. (eds) Reliability and Statistics in Transportation and Communication. RelStat 2019. Lecture Notes in Networks and Systems, (17), Springer cham.

Sahni, U. 2015. Personal communication. In: Today's challenges for girls' education. Available at www.ungei.org/Todays-Challenges-Girls- Educationv5.pdf. Accessed on 30 October 2019.

Stephanie, S. P. 2013. Science gender gap: five reasons women trail men in science Live Science. Available at https:// www.huffingtonpost.com/2013/03/07/science-gender-gap-fivereasons-men n-2827567.html. Accessed on 17 October 2019.

United Nations Children's Fund New York. 2018. Evaluation of UNICEF Girl's Education Portfolio (2009-2015). Available at https://www.unicef.org/evaldatabase/files/UNICEF. Accessed on 14 October 2019.

Zaborova, E. N., \& Markova, T. L. 2016. Students as social actors of virtual educational environment. Actual Issues of Sociology of Culture, Education, Youth and Management: Materials of the All-Russian Scientific Conference with international participation. Yekaterinburg, Russia. 392-397. 